Acta vet. scand. 1972, 13, 185-190.

From the Department of Physiology, College of Veterinary Medicine, Helsinki, Finland.

\title{
A STUDY OF THE EFFECT OF SHORT-TERM PROGESTERONE TREATMENT ON SERUM CALCIUM AND INORGANIC PHOSPHORUS CONCENTRATION IN THE RAT
}

\author{
By \\ Pekka Nurmio and Maija Valtonen
}

NURMIO, PEKKA and MAIJA VALTONEN: A study of the effect of short-term progesterone treatment on serum calcium and inorganic phosphorus concentration in the rat. Acta vet. scand. 1972, 13, 18519.0. - Four intact and four parathyroidectomized rats, fed with a low calcium diet, were treated with progesterone, $0.7 \mathrm{mg}$ s.c. daily on four consecutive days, and the effects of the treatment on the serum calcium and inorganic phosphorus were investigated. Four untreated intact rats on the same diet served as controls. The treatment was found to have no influence on the concentrations of the serum calcium or inorganic phosphorus.

progesterone; serum Ga; serum P; paresis.

Very little is known of the possible interactions of progesterone and calcium metabolism. This hormone, however, has been recommended among other things for paresis prophylaxis (Derlogea 1956, Gerola 1962), although these recommendations have not been confirmed with any data.

In the bird the hypercalcemia induced by estrogens is enhanced by progesterone (Wright et al. 1959), and in this species progesterone has also been found to reduce the elevating effect of exogenous estrogen on the serum alkaline phosphatase (Brown \& Badman 1961).

Recently, Payne (1970) and Gustafsson et al. (1970) have reported results of progesterone administration in cattle. In Payne's trials a single prepartal administration of progesterone 
significantly depressed the plasma inorganic phosphorus in parturition, while the results of Gustafsson et al. suggest an opposite effect of the hormone. Plasma calcium was not found to be affected in either of the studies, and only in Payne's trial could a tendency to a lowered paresis incidence be noticed.

Belonje et al. (1969) have published data on the action of progesterone on the thyroid of the lamb. The seven days' progesterone treatment was found significantly to increase the thyrocalcitonin content of the thyroids, while no distinct effect was seen in plasma calcium in the treated lambs.

Since the studies available were not felt to give sufficient information about the possible applicability of progesterone for paresis prophylaxis, two experimental series were planned to test the hormone for this purpose. This paper presents the results of the first trial, in which the effect of a short-term progesterone treatment on the serum calcium as well as on the serum inorganic phosphorus level was investigated in intact and parathyroidectomized rats.

\section{MATERIAL AND METHODS}

The material consisted of 12 immature female albino rats. The rats were fed with a low calcium diet consisting of

$\begin{array}{lc}\text { wheat bran } & 45 \% \\ \text { casein } & 30 \%, \\ \text { glucose } & 10, \\ \text { vegetable oil } & 10, \\ \text { yeast } & 2.5, \\ \mathrm{CaCO}_{3} & 1.5, \\ \mathrm{NaCl} & 1.0,\end{array}$

After being accustomed to the diet four of the rats (Group A) were parathyroidectomized by electrocautery (Zarrow et al. 1964). The thyroid gland was left intact. The completeness of parathyroidectomy was controlled by following the fall of serum calcium levels after the operation. Four days later the rats were injected with $0.7 \mathrm{mg}$ progesterone ('Protormone' Burroughs Wellcome \& Co.) s.c. together with four intact rats (Group B). The treatment with progesterone was continued daily on four consecutive days. The remaining four rats (Group C) served as untreated controls. 
The blood samples were obtained daily by warming the tail under an incandescent bulb prior to cutting off the tip of the tail. In the groups treated with progesterone the sampling preceded the injection every day. The daily samples needed for the serum inorganic phosphorus analyses were obtained by uniting samples of equal volume of serum taken from each of the four rats in each respective group. The serum specimens were analyzed for calcium by Perkin-Elmer atomic absorption spectrophotometry, and for inorganic phosphorus according to the method by Fiske \& SubbaRow (1925) (modif.). All the analyses were made in duplicate.

\section{RESULTS}

The values of the serum calcium and inorganic phosphorus during the course of the study appear in Table 1 and Fig. 1. The serum calcium was slightly elevated in the intact progesterone-

Table 1. The serum calcium and inorganic phosphorus in the progesterone-treated parathyroidectomized (Group A), progesteronetreated intact (Group B) and control (Group C) rats (Ca and P, $\mathrm{mg} / 100 \mathrm{ml}$ serum).

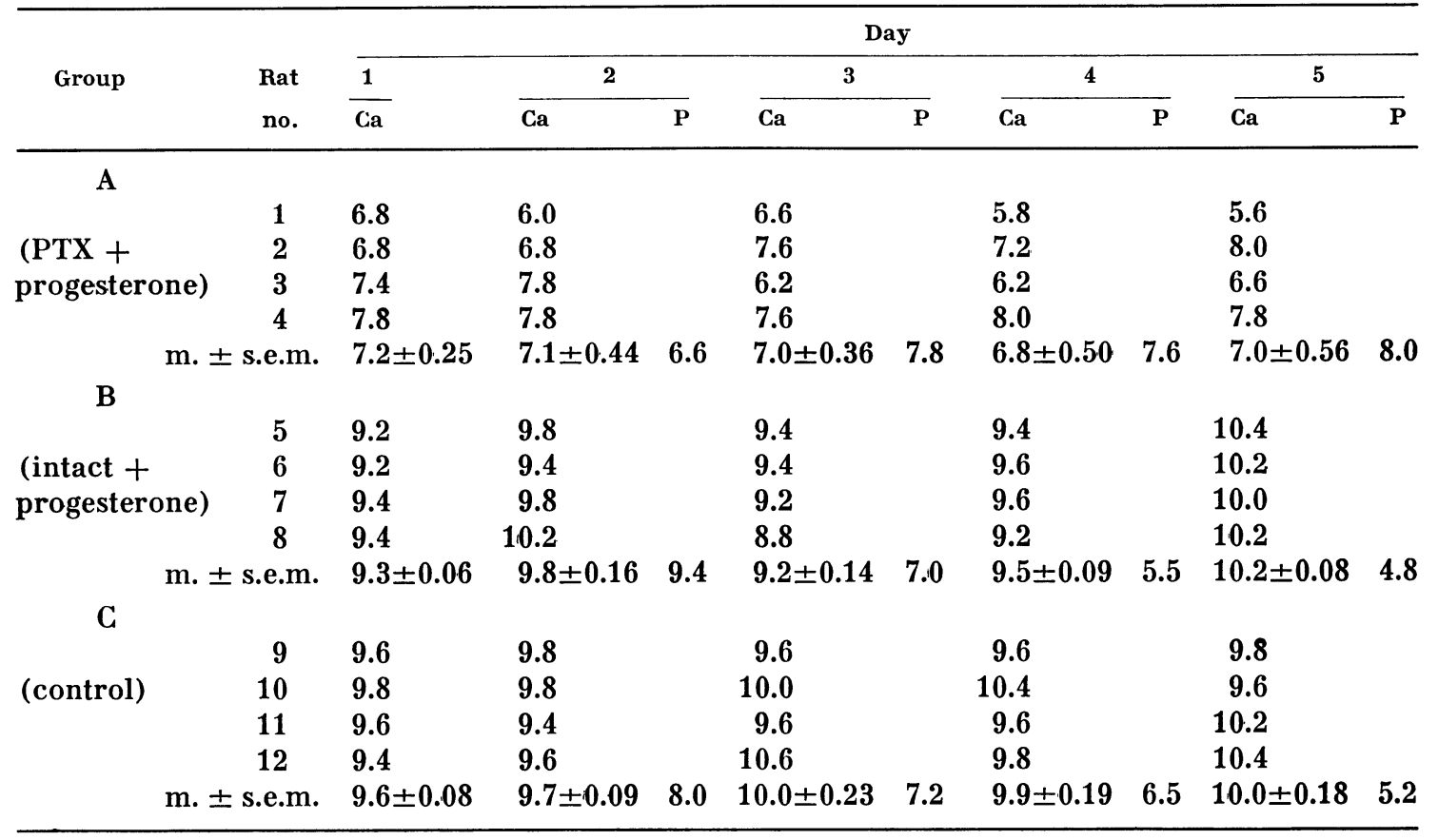


treated rats and in the control rats (groups $\mathrm{B}$ and $\mathrm{C}$ ). In these groups the serum inorganic phosphorus content was distinctly lowered in contrast to the parathyroidectomized progesteronetreated rats (Group A), in which a slight rise of inorganic phosphorus could be perceived.

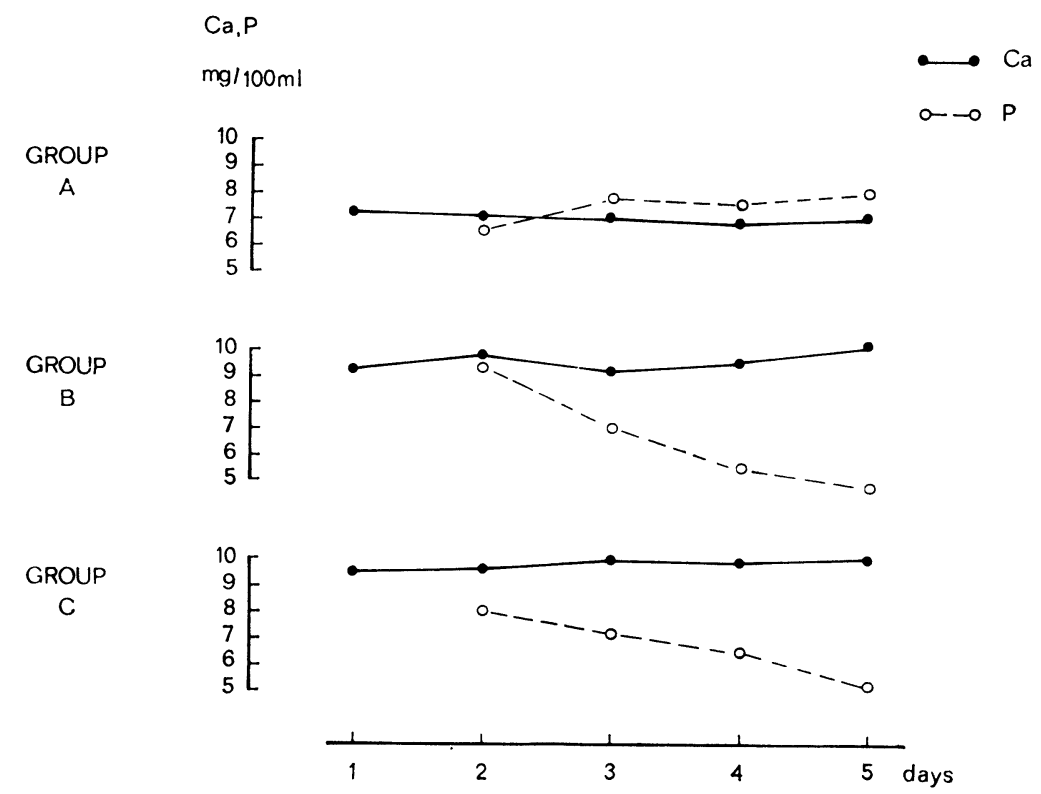

$\mathrm{Fig}$ u r e 1. The changes in the serum calcium and inorganic phosphorus during progesterone treatment in the parathyroidectomized (Group A) and intact (Group B) rats. Group C = untreated control rats.

\section{DISCUSSION}

Short-term progesterone treatment does not seem to have any influence on the serum calcium concentration in the rat. This is indicated by the constancy of the mean serum calcium values in the progesterone-treated parathyroidectomized rats. Accordingly, the rising tendency of the serum calcium in the progesterone-treated intact rats is most likely not caused by the progesterone but by the endogenous parathyroid hormone PTH induced by the low calcium content of the diet. This is proved by the fact that serum calcium is also increased in the untreated control rats, and also by the fact that the rise of calcium is accompanied by a drop in the serum inorganic phosphorus a phenomenon characteristic of a PTH response. 
Owing to the absence of PTH response in the parathyroidectomized group the serum inorganic phosphorus in these rats shows, as one might expect, a tendency towards elevated values. Accordingly, the rise of the serum inorganic phosphorus in Group A hardly offers evidence of a progesterone effect of this particular kind. This conception is further confirmed by the marked fall in the inorganic phosphorus in the other progesterone treated group, Group B.

\section{REFERENCES}

Belonje, P. C., C. H. van Niekerk, I. M. R. van Aarde \& G. L. Smit: The influence of progesterone and stilboestrol on the thyrocalcitonin content of sheep thyroids. J. S. Afr. vet. med. Ass. 1969, 40, 179-182.

Brown, W. O.\&H. G. Badman: Effects of oestradiol and progesterone on serum alkaline phosphatase in the fowl. Poultry Sci. 1961, 40, 819-820.

Derlogea, H.: Contributions to the etiology, pathology and prophylaxis of milk fever. III Int. Congr. Animal Reproduction, Cambridge 1956, Plenary papers p. 135.

Fiske, G. H. \& Y. SubbaRow: The colorimetric determination of phosphorus. J. biol. Chem. 1925, 66, 375-400.

Gerola, E.: Ancora in tema di ormoni e collasso puerperale. (Hormones and milk fever). Gazz. vet. 1962, 15, 12-14.

Gustafsson, B., L. E. Edqvist, L. Ekman, L. ölund, B. Olsson \& S. Carstam: Parenteral administration of progesteron to pregnant cows with special reference to its influence on $\mathrm{Ca}$ - and $\mathrm{P}$ levels in blood and on the course of parturition and puerperium. XI. Nord. Vet.-Kongr., Bergen 1970. Proc. 235.

Payne, J. M.: Some recent work on the pathogenesis and prevention of milk fever. In Parturient Hypocalcemia, ed. John J. B. Anderson, Acad. Press, New York and London 1970, 1-13.

Wright, L. A., W. A. Maw \& R. H. Common: An effect of progesterone on estrogen-induced hypercalcemia in the sexually immature pullet. Canad. J. Animal Sci. 1959, 39, 137-144.

Zarrow, M. X., J. M. Yochim \& J. L. McCarthy: Experimental Endocrinology. Acad. Press, New York \& London 1964.

\section{SAMMANFATTNING}

Undersökning över inverkan av kortvarig progesteron behandling pă serum kalsium och oorganiskt fosfor hos råtta.

Fyra normala och fyra parathyroidektomerade råttor utfodrades med en kalsiumfattig diet samt behandlades med progesteron injektioner, $0,7 \mathrm{mg}$ subcutant dagligen, fyra dagar $\mathrm{i}$ följd. Inverkan av 
denna behandling på kalsium och oorganiskt fosfor i blodserum undersöktes. Fyra obehandlade, normala råttor på samma kalsiumfattiga diet tjänade som kontroller. Ingen inverkan av behandlingen kunde konstateras på koncentrationen av kalsium och oorganiskt fosfor i blodserum.

(Received March 22, 1971).

Reprints may be requested from: Pekka Nurmio, Department of Physiology, College of Veterinary Medicine, Helsinki 55, Finland. 